\title{
Investigating Malaysian Secondary School Mathematics Teachers' Perception of National Philosophy of Education
}

\author{
Abdolreza Lessani ${ }^{1}$, Aida Suraya Md Yunus ${ }^{1}$, Rohani Ahmad Tarmiz ${ }^{1} \&$ Rosnaini Mahmud $^{1}$ \\ ${ }^{1}$ Faculty of Educational Studies, Univesiti Putra Malaysia, Serdang, Selangor, Malaysia \\ Correspondence: Abdolreza Lessani, Faculty of Education, Univesiti Putra Malaysia, 43400 Serdang, Selangor, \\ Malaysia. Tel: 601-3259-3609. E-mail: reza.lessani2012@gmail.com
}

Received: August 1, 2014 Accepted: September 2, 2014 Online Published: September 28, 2014

doi:10.5539/ies.v7n10p122 URL: http://dx.doi.org/10.5539/ies.v7n10p122

\begin{abstract}
The purpose of this study is to investigate the Malaysian secondary schools mathematics teachers' perceptions towards the National Philosophy of Education (NPE) and its applications in their teaching practices in their classes. A qualitative and case study approach was used for this study. The participants were secondary schools teachers of mathematics with at least three years of teaching experiences in eighth grade (Form 2), who were selected using the snowball sampling method. Due to the aim of this study and in order to identify the teachers' perceptions of the national philosophy of education, interviews were conducted with seven teachers, and it was counterchecked with the documents of the Ministry of Education (MOE) in Malaysia to find out how familiar the participants were with the MOE aims and guidelines. Moreover, observations were conducted to examine teaching practices of the teachers to find out how they reflect on the guidelines of Malaysia MOE in determining their teaching practices. Analysis of the data revealed that the teachers had some knowledge of national philosophy of education in Malaysia. However, they had different perspectives of the aims and objectives of NPE so that each of them came up with her own approach. Furthermore, the teachers and MOE aims were to build up individuals who deeply believe in God and they attempted to adopt the educational syllabus of Malaysian schools to achieve the national goals toward producing the knowledgeable and competent students in Malaysia.
\end{abstract}

Keywords: mathematics teachers, national philosophy of education, ministry of education Malaysian, mathematics, educational mathematics

\section{Introduction}

Mathematics education has always been treated as an important section of general education and specifically science education (Shahrill \& Clarke, 2014). Mathematics became the driving force for almost all technological and scientific developments in the 19th and 20th century. Scientific and mathematical models and their transformation into technology had big influence on natural, economies, and social sciences (Reyna \& Brainerd, 2007). They also had large impact on all activities in the professional, social and daily life (Maasz \& Schloeglmann, 2006).

Formal Education in Malaysia dates back to the time that the country was a British colony. Before that, education in Malaysia was intended only to teach some life skills to students. For example, the first College in Malaysia, that is, Sultan Idris Training College (today is called Universiti Pendelikon Sultan Idris) was established in 1922 to train Malaysian teachers how were to teach skills such as, weaving and planting chilies and papayas, and some basic reading and writing competencies at the minimum level (H. Ismail \& M. Ismail, 2011). When British entered Malaysia, they started a reform in Malaysian educational system. A British officer (Dussek) was appointed as the head of the Sultan Idris College and he started compiling basic textbooks for educational use. Then, some mathematics textbooks were published for the first time to be used at the Malaysian schools (H. Ismail \& M. Ismail, 2011). The British build new system of education in Malaysia based on a secular education using the Western styles. The British curriculum that was implemented in colonized India in 1850s was adopted in Malaysia as well. The first mathematics textbook was called Kitab Hisab written by Durell which includes logic, algebra, and geometry (H. Ismail \& M. Ismail, 2011). In 1967, modern mathematics was implemented in Malaysia by a Scottish Mathematics group. This group was inspired by a western mathematical philosophy, that is, laicism by Russell and it was adopted in the schools in Malaysia till 1980s when a reform in 
education took place and a holistic and integrated philosophy in education was introduced (H. Ismail \& M. Ismail, 2011).

In the early years after the independence of the country in 1965, Malaysian educators tried to make some changes in the education system to fulfill the needs of the nation and to promote national unity. In 1970s, the medium of instruction was changed to Malay language except the primary level to promote national unity and integration. A need for technology and science was highly recognized to promote the development of the country, so Malaysian educators made more emphasis on these fields. Hence, by the end of 1970s, 68 technical and vocational schools were established in Malaysia. Then, the Education Review Committee was set up by Dr. Mahathir Mohammed with the aim of reviewing education system to identify if it meets the national needs. The education in Malaysia was shifting toward holistic approaches. The Malaysian authorities then recognized a need to induce values into education and develop integrated students in terms of faith (Curriculum Development Centre, 2002, 2004). Gradually, the Western secular education was mixed with noble values which influenced all subjects including mathematics. In 1987, the National Philosophy of Education (NPE) was compiled which aimed to promote holistic and integrated approaches to the Malaysia education system.

The Malaysian Ministry of Education (2006) elaborates on general education in Malaysia. The country's educational goals are manifested in the Malaysian National Philosophy of Education (NPE) as follows:

Education in Malaysia is an ongoing effort towards further developing the potential of individuals in a holistic and integrated manner so as to produce individuals who are intellectually, spiritually, emotionally and physically balanced and harmonious, based on a firm belief in God. Such an effort is designed to produce Malaysian citizens who are knowledgeable and competent, who possess high moral standards, and who are responsible and capable of achieving a high level of personal well-being as well as being able to contribute to the betterment of the family, the society and the nation at large (Curriculum Development Centre, 2006, p. vi).

According to Ismail and Awang (2009), NPE is the most important document that shows the guidelines and directions of Malaysian Education system and its first and main principle is the 'belief and devotion to God'. In other words, individuals' character formation based on moral and religious values are taken seriously in NPE (Ismail et al., 2009).

It is widely acknowledged that what teachers believe influences their teaching outcomes (Beswick, 2006). Moreover, true application of the guidelines of the national philosophy of education in teaching the students, it is indeed a key factor which can influence the achievement of students in mathematics, there is a need to understand the perception of Malaysian secondary school mathematics teachers of the national philosophy of education and the applications of this philosophy in their teaching practices in their classes.

\section{Research Method}

For this research, a qualitative case study was employed to identify the teachers' perceptions toward the philosophy of education in Malaysia and its applications in their teaching practices. We selected two public secondary schools located in Serdang and Putrajaya in the provinces of Selangor and the Federal Territory, respectively, to collect the data. The participants of this study were seven teachers of mathematics with at least three years of teaching experience in eighth grade (Form 2), who were selected using the snowball method.

In this article, firstly the backgrounds of the seven participants are presented, and secondly data analysis is arranged and categorized based on the research questions. In order to identify the teachers' perceptions of the National Philosophy of Education (NPE), interviews were conducted with the teachers, and it was counterchecked with the documents of the Ministry of Education (MOE) in Malaysia to find out how familiar the participants were with the MOE aims and guidelines. Moreover, interviews and observations were used to analyze teaching practices of the teachers to find out how they reflect on the guidelines of Malaysia MOE in determining their practices.

\section{Findings}

The participants of this study were seven teachers teaching eighth grade who were selected using the snowball method in two secondary schools in Seri Serdang and Putrajaya. The background information of the teachers is shown in Table 1.

As Table 1 shows, the teachers' age ranged from 28 to 52, so the participants included both young and older teachers. They were all female and married. All participants happened to be female since the number of female teachers in secondary schools in Malaysia outnumbered the males. The majority of the teachers had one to three children, and two of them had four children. The number of children and family status was important to the 
researcher as this may affect the time that they spend for their teaching activities. The distance from teachers' house to school ranged from 1 to 25 kilometers. Only two of the teachers were living near their schools, i.e. one kilometer away from the school. But the majority of the teachers lived far from the schools, consequently, they had to spend a long time every day travelling between their house and school.

Regarding their mathematics teaching experiences, there were both very experienced and rather novice teachers among the participants. Their mathematics teaching experiences ranged from 4 to 25 years, and the majority had around 5 years of teaching experience.

Table 1. Participants' background

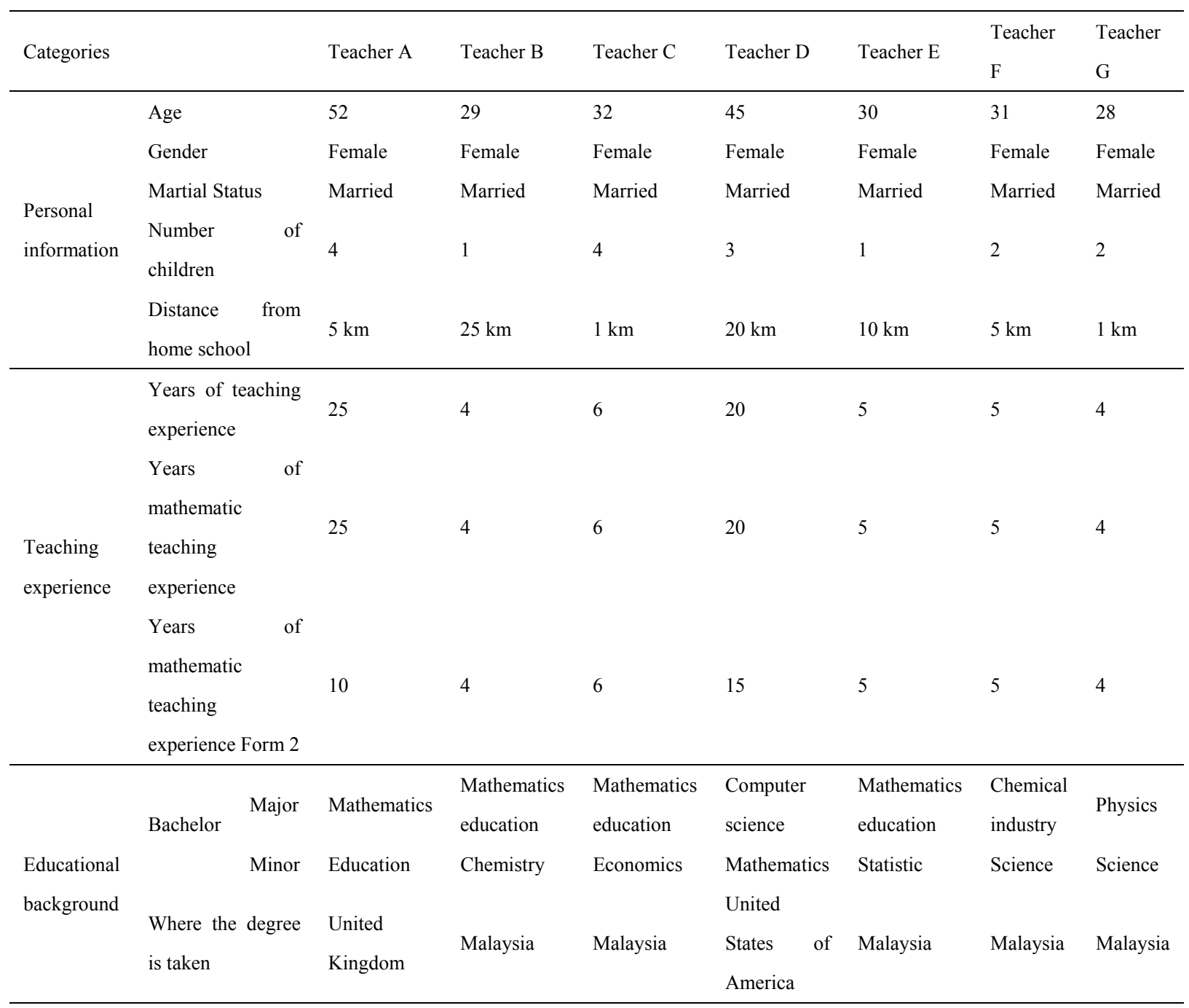

All the participants had been teaching mathematics since they started working as a teacher. Their teaching experience in Form 2 ranged from four to 15 years, meaning that they all had enough experiences in teaching Form 2 which was an important factor to this study. All of the teachers had bachelor degrees and most of them majored in mathematics; three of them majoring in computer sciences, chemical chemistry and physics. They got their minor in education, chemistry, economic, mathematics, statistics, and sciences respectively. However, only one of the teachers minored in mathematics and another one in education, and the rest of them minored in different fields of studies. Five participants graduated from public universities in Malaysia and the other two graduated from United Kingdom and United States of America.

In this section, the participants' perceptions of the National Philosophy of Education (NPE) in Malaysia are presented. The findings of the interviews are summarized in the following. In order to conduct a more in-depth analysis of (NPE) among the selected Malaysian teachers, an interview was conducted with the participants. The 
researcher asked 11 questions to find out the teachers' understandings of the aims and guidelines of the MOE's mathematics education. The questions were drawn from, the Curriculum Development Center (CDC) Form 2 (2002) and the Integrated Curriculum for Secondary Schools Syllabus Mathematics (2004).

These questions are categorized based on the following themes: Teachers' knowledge of vision and mission, encouraging students spiritually and emotionally, encouraging students to be competent, enhancing morality, encouraging students to be responsible, contributing to the nation, reinforcing individual values, improving thinking skills for problem solving, preparing for future challenges, providing equal opportunity to students, and flexibility of math education. In this section, we also present and discuss the findings of the study based on the observations of behaviors of the teachers in their classes.

In response to the above-mentioned questions, teacher A had a spiritual-educational approach toward the national philosophy of education. The interview and observation showed that her teaching had an Islamic flavor and she attempted to mix spirituality with mathematics teaching. As the most experienced teacher among the participants, she was skillful in handling the class, the teaching, and the troublesome students. She treated all students equally and did not practice favoritism. She had a good knowledge of mission and vision of National Philosophy of Education. Teacher A' observation results were consistent with those of interview emphasizing her commitment to practice what she believed in.

The results of observation and interviews with teacher B showed that she had a motivational approach and attitude towards the philosophy of education. She used to find ways to encourage mathematics learning in students. For example, she used to give some prizes to students who did well in exercises or were well-organized. The researcher also observed that she gave small prizes, such as, beautiful cards, pencils, or erasers to the students or just encouraged them verbally. She did know much about the National Philosophy of Education, however, to her, motivation was the key to philosophy of education.

Teacher Chad some knowledge of the National Philosophy of Education and was looking at it as a base to develop organized and independent students capable of critical thinking. She emphasized problem solving approaches as well as relating mathematics to everyday life as a means to encourage thinking skills. The observation also showed that she used to give a lot of new exercises to the students after each section and encourage them to think on them. She emphasized the importance of discipline and accuracy and asked the students to be organized and accurate. She believed that flexibility would decrease accuracy, so she was not compromising on the students' activities and had high expectations during the class. During the class, she seemed to be a strict teacher, however, the students seemed to be feeling rather comfortable. However, some of the weak students seemed to be shy to take part in class activities, fearing that they may make a mistake.

Although teacher D had little knowledge of the formal National Philosophy of Education, she used to maintain a balance between mathematics education aims and students' responsibilities. She believed that if students know the reasons behind why they need to take mathematics learning serious, and then they would commit themselves more to learning. Observation also showed that she used to emphasize the role of mathematics education in making a better future for the students. She used to ask the students what their favorite job is and then she explained how mathematics would help them in that job. She also used to increase self-esteem and self-confidence in the students reminding them that how they are blessed in life with a healthy body and sound mind and they have to be thankful to God for that. The observation showed that she did not discriminate between the students and was flexible in teaching method and switching to the one that suit the class the best.

Teacher E had a good knowledge of National Philosophy of Education and was committed to follow it. She was more in favor of making the learning environment interesting for the students. Observation also showed that she used to have fun during the teaching and cheer the students up. She believed that to make students ready for future challenges they need to do a lot of problem solving exercises. So, she saw problem solving as a means to teach students the life skills. Also she used to apply cooperative activities such as group works to help students how to interact in a community. She did not discriminate between the students and gave them all equal opportunities to show their abilities. The observation showed that she was very involved in improving the weak students' mathematics learning.

Teacher F looked at the philosophy of education with a humanitarian approach. She believed that the priority in education is to make students be a better human being. She aimed at encouraging responsibility in the students and asked them help each other during the class activities. The observation also showed that she was insisting on students help each other to promote their sense of humanity and cooperation. During the class, she used to verbally reward the students who did help other students and encourage it. She believed that the philosophy of education is all about being a better human and survive in the society. She was flexible in her teaching and used to apply the 
method that seemed to be appropriate.

Finally, Teacher $\mathrm{G}$ believed that the philosophy of education is more about creating efficient leaders to develop the society. She was looking at education as a means to nurture the society. Then she attempted to train responsible students and promote critical thinking. The researcher observed that she had emphasis on group work and problem solving activities and used to challenge students with innovative and creative problems. She believed that mathematics is the basis for all other sciences and the key to success. She believed that mathematics would help students develop morality as well. During her teaching, she attempted to make students think and do not take everything for granted. She was flexible in her teaching and used the method she thought to be appropriate for the class and the specific activity.

\section{Discussion}

Based on the findings of the interview with the teachers, observations and document analysis (CDC, 2002, 2006), this study revealed that secondary school teachers and MOE aim to build up individuals who deeply believe in God. A number of researches (Ismail et al., 2009) also indicated that the secondary school teachers in Malaysia held a strong belief in God. However, they attempted to adopt the educational syllabus of Malaysian schools to achieve the national goals toward producing the knowledgeable and competent students in Malaysia.

The investigation of the philosophy of education in Malaysia in the current study added more understanding regarding the philosophy of education. It was found that the aim of education in Malaysia is producing Malaysian citizens who are competent and knowledgeable, who hold great moral principles, and who are responsible and able to achieve a high level of individual well-being and also being capable of contributing to the improvement of the society, the family, and the nation. Malaysia emphasizes the development of mathematical thinking and problem solving skills, development of the positive approaches toward mathematics, making students innovative, and utilizing Information and Communication Technology as well as other technologies (CDC, 2006). As the results, teachers' responses to some questions were rather scattered, but tended to go towards agreement rather than the opposite. The overall results showed that teachers had different approaches toward the same topic. For example, regarding the possible ways of enhancing pupils' morality, some of the teachers emphasized the role of encouraging responsibility, while some others talked about doing more practices in the class. Some of them also talked about emphasizing group work activities, and the others suggested assignments, disciplines and being organized. In a few cases, majority of the teachers had the same idea. For example regarding having flexibility in mathematics education, the majority of the teachers believed that mathematics education is flexible and teachers can choose the teaching practice and approaches that more suit their class.

According to the Curriculum's Vision and Mission, and the National Philosophy of Education in Malaysia "education is an ongoing effort to produce individuals who are intellectually, spiritually, emotionally and physically balanced and harmonious based on a firm belief and devotion to God" (CDC, 2002, p.vii). The researcher asked some questions about the vision and mission of Malaysia education to find out how teachers are familiar with MOE Curriculum's vision and mission. The analysis of responses showed that majority of the participants had little familiarity with the vision and mission as indicated in the documents of MOE. Two of the teachers had no ideas about the vision and mission and the others partially knew some of the aims and objectives. However, teachers A, C, and E even referred to the phrases mentioned in the documents of MOE that indicates their high knowledge of MOE's vision and mission.

The teachers were asked how they encouraged their students spiritually and emotionally. Majority of the teachers emphasized on the role of motivation in enhancing the spirituality and emotionality of students. Teachers A and $\mathrm{D}$ indicated that encouraging the belief in God in the students and attending to Islamic principles would help a lot. Teacher A seems to have more emphasis on the role of relating mathematics topics to faith. This approach seems interesting, however, considering the fact that Malaysian students come from different religion backgrounds, it may seem confusing for some of the students. Other teachers had different approaches such as providing an interesting class for the students, and reinforcing discipline, organization, and self-confidence in the students. Teacher $\mathrm{C}$ and $\mathrm{F}$ have the same attitudes regarding spirituality and emotions. As they mentioned, they gave advices to the students in this regard. The responses showed that the teachers are concerned about enhancing the students' spirituality and emotionality and so they followed their own approaches to obtain this aim.

The goal and aims of mathematics education for secondary school in Malaysia is producing individuals who are thinking mathematically and apply mathematic in their daily life to solve problems and make proper decisions. This ability prepares them to face the challenges in everyday life (CDC, 2004). Majority of the teachers stated 
that in order to encourage mathematics competencies in their students, they make them do more practices in class and increase their cooperation and group work activities. Teacher A suggests extra classes for students who are less competent. Teacher B indicated that she gives prizes to students to encourage them and thereby increase their mathematics competence. The others highlighted the role of giving assignments, and advice, as well as reinforcing responsibility in developing students' mathematics knowledge and competencies.

The responses of the teachers on 'how the mathematics class could enhance students' learning and achievements' were more related to class activities, such as increasing group work activities and doing more practices in class. It seems that the role of class activities and assignments in enhancing morality is overemphasized. In other words, some teachers believed that reinforcing discipline and responsibility will lead to enhancing morality among the students.

To increase responsibility among the students, the majority of the teachers emphasized the role of assignments and encouraging the students to be organized. Thus, responsibility, according to the participants, can be enhanced in the students through setting up an organized environment in class where there is a mutual respect between the teacher and students. Giving direct advices and counseling are also suggested by the teachers.

Moreover, two of the teachers believed that since mathematics is the basis for all of the other sciences, it helps students in their future career and thereby contributes to prosperity and development of the nation. Two of the teachers believed that relating mathematics to daily life would help the students contribute to the nation development.

The teachers had different approaches to reinforce personal values in the students. Three of them said that they improve self-confidence in their students through expressing positive opinions about them and acknowledging their abilities. Other teachers give different opinions such as giving prizes, tests, high marks and pandect to value the students and encourage them to learn mathematics better.

Regarding improving thinking skills in the students, majority of the teachers suggested problem solving approaches to mathematics teaching. They also indicated that they give challenging questions to the students to make them think. Furthermore, two of the teachers stated that through relating mathematics to everyday life they encourage their students to think. Thus, the majority of teachers seem to follow constructive approaches to encourage the students to think. However, two of the teachers overemphasized the role of assignments in improving thinking skills. They believed more practices in the class would encourage students to think more.

Mathematics education, according to MOE mathematics curriculum, should enable students to be prepared for future changes and challenges (CDC, 2002). Majority of the participants in this study believed that since mathematics is the basis for all of the sciences, it helps students in their future challenges and careers. Moreover, two of the teachers believed in the role of mathematics education in preparing students for their future challenges.

The mathematics curriculum in Malaysia, in line with the National Education Philosophy "provides equal opportunities to pupils from various backgrounds and levels of abilities to acquire mathematical skills and knowledge" (MOE, 2002, pix). The research participants were asked about their approaches for providing equal opportunities for all of the students. The teachers had almost the same approach to providing students with equal mathematics learning opportunities. All of the teachers asserted that they avoid discrimination among their students through different ways, including allocating the same time to all of the students, giving the same services to all, being fair on marking their papers, and attending to all. Furthermore, according to teacher A and teacher F, providing equal opportunities for students does not mean giving the same questions to all students. They believe that the exams should match the students' abilities. Teacher A also, indicated that giving similar questions to all is not fair but believed in providing equal opportunities for all. Therefore, the participants agreed with the broad aims of mathematics education in providing equal opportunities for the students.

The Malaysia Mathematics Curriculum advocates flexibility of teachers "to implement an enjoyable, meaningful, useful and challenging teaching and learning environment" (MOE, 2002, p. xi). All of the participants of the study, except one, also emphasized the important role of flexibility in mathematics education. Therefore, majority of the teachers were familiar with the guidelines of MOE for mathematics education. Moreover, teachers stated that they change their teaching strategy according to the need of their students. However, teacher $\mathrm{C}$ believed that flexibility means less accuracy and mathematics education is therefore fixed. Teacher $\mathrm{C}$ also indicates that teaching methods may be flexible but mathematics in its nature is not flexible.

On the other hand, the results of the indirectly observations showed that the teachers were following almost the same approach. Regarding encouraging the students spiritually and morally, almost all of the teachers had good 
emotional relations with their students. They usually entered the class with a happy face and kept a good mood during their teaching. Also, all of the teachers valued the students in the class. The students were allowed to participate in all the class activities and share and discuss their ideas. All the teachers valued the students' thinking. However, most of the teachers did not give direct feedbacks to the students about their ideas. Majority of the teachers used to improve the students' responsibility and competencies. They allowed group discussions and let the students monitor their own progress in learning the skills. Regarding encouraging the thinking skills in the students, also majority of the teachers provided opportunities for the students to think about mathematical subjects and ask questions skillfully. Also, all of the teachers were avoiding discrimination among the students and regarded all the students the same.

\section{Conclusion}

In this study, we attempted to understand secondary school teachers' perceptions of the national philosophy of education in Malaysia and its applications in their teaching practices. In this respect, the philosophy of mathematics education based on the written documents of the Ministry of Education in Malaysia was discussed. According to the curriculum principles of Ministry of Education in Malaysia (2006), education is a means to develop the personality and character of individuals and there is a high emphasis on building students' morality. It is stated that the aim of education is "to produce individuals who are intellectually, spiritually, emotionally and physically balanced and harmonious, based on a firm belief in God". Also, individuals are supposed "to contribute to the betterment of the family, the society and the nation at large" through education. Hence, there is an emphasis on developing personal characteristics and competencies of students and the education of individuals that is considered as a means to build individuals to be helpful for improving their society.

It was found that in Malaysia, the aim of education is producing citizens who are competent and knowledgeable, who hold great moral principles and who are responsible and able to achieve a high level of individual well-being and contribute to the improvement of the society, the family, and the nation at large (Ministry of Education Malaysia, 2006). The Malaysian Ministry of Education focuses on developing potential of individuals through quality education. The outcome of this individual development is to serve the society and nation. The aim of mathematics education is indicated as "to inculcate noble values and love for the nation in the development of a holistic person, who in turn will be able to contribute to the harmony and prosperity of the nation and its people." It seems that the MOE philosophy of education in Malaysia is more society-centered. For example, Malaysian MOE considers mathematics as an essential tool to help the progression of society and nation. In this respect, the present study showed that the philosophy of education in Malaysia is relatively highly developed in that it aims to train students as balanced and harmonious individuals with a strong belief in God.

\subsection{Limitation and Future Directions}

The present study is associated with few limitations. Firstly, we sufficiently assessed the mathematics teachers' familiarity with National Philosophy of Education among public high-schools (using the qualitative case study and snowball sampling technique), but, future studies can capture the mathematics teachers' familiarity with National Philosophy of Education among private high-schools and highlight any potential differences. Secondly, we only interviewed with and observed mathematics teachers from the $8^{\text {th }}$ grade. Future studies can complement our research by interviewing with mathematics teachers from other grades in secondary schools in Malaysia and assess whether the level of familiarity with National Philosophy of Education differ among different grades.

\section{References}

Beswick, K. (2006). The importance of mathematics teachers' beliefs. Australian Mathematics Teacher, 62(4), $17-21$.

Curriculum Development Centre. (2002). Integrated curriculum for secondary schools: Curriculum specifications mathematics Form 2. Kuala Lumpur: Curriculum Development Centre, Ministry of Education Malaysia.

Curriculum Development Centre. (2004). Integrated curriculum for secondary schools; syllabus mathematics. Kuala Lumpur: Curriculum Development Centre, Ministry of Education, Malaysia.

Curriculum Development Centre. (2006). Integrated Curriculum for Secondary Schools: Curriculum Specifications Mathematics Form 4. Kuala Lumpur: Curriculum Development Centre, Ministry of Education Malaysia.

Ismail, H., \& Ismail, M. R. (2011). Infusion of values into teaching mathematics in higher institution of learning in Malaysia: A philosophical reflection. Paper presented at The New Trends on Global Education Conference 2011, Turkish Republic of Northern Cyprus. 
Ismail, N. A., \& Awang, H. (2009). Mathematics achievement among Malaysian students: What can they learn from Singapore? International Education Studies, 2(1), 8-17. http://dx.doi.org/10.5539/ies.v2n1p8

Maasz, J., \& Schloeglmann, W. (2006). New mathematics education research and practice. Rotterdam: Sense Publishers.

Reyna, V. F., \& Brainerd, C. J. (2007). The importance of mathematics in health and human judgment: Numeracy, risk communication, and medical decision making. Learning and Individual Differences, 17(2), 147-159. http://dx.doi.org/10.1016/j.lindif.2007.03.010

Shahrill, M., \& Clarke, D. J. (2014). Brunei teachers' perspectives on questioning: Investigating the opportunities to "Talk" in mathematics lessons. International Education Studies, 7(7), 1-18. http://dx.doi.org/10.5539/ies.v7n7p1

\section{Copyrights}

Copyright for this article is retained by the author(s), with first publication rights granted to the journal.

This is an open-access article distributed under the terms and conditions of the Creative Commons Attribution license (http://creativecommons.org/licenses/by/3.0/). 